\title{
CORRECTION
}

View Article Online

View Journal I View Issue

\section{Correction: Efficient gene transfection to liver cells via the cellular regulation of a multifunctional polylactitol-based gene transporter}

Cite this: J. Mater. Chem. B, 2016,

4, 2740

Young-Dong Kim, ${ }^{\text {a }}$ Tae-Eun Park, ${ }^{\text {b }}$ Bijay Singh, ${ }^{b}$ Kye-Soo Cho, ${ }^{a}$ Jaiprakash N. Sangshetti, ${ }^{c}$ Yun-Jaie Choi, ${ }^{b}$ Rohidas B. Arote ${ }^{\star a}$ and Chong-Su Cho*b

DOI: $10.1039 / c 6 t b 90045 c$

www.rsc.org/MaterialsB

Correction for 'Efficient gene transfection to liver cells via the cellular regulation of a multifunctional polylactitol-based gene transporter' by Young-Dong Kim et al., J. Mater. Chem. B, 2016, 4, 2208-2218.

The authors wish to replace the Acknowledgements section in the published article with the following text:

This work was supported by a National Research Foundation of Korea (NRF) grant funded by the Korea Government (MSIP) (2015-R1A2A2A03004448) and the Oromaxillofacial Dysfunction Research Center for the Elderly (No. 2015048003) at Seoul National University, Korea.

The Royal Society of Chemistry apologises for these errors and any consequent inconvenience to authors and readers.

\footnotetext{
${ }^{a}$ Department of Molecular Genetics \& Dental Research Institute, School of Dentistry, Seoul National University, Seoul, 110-749, Republic of Korea. E-mail: rohio6@snu.ac.kr; Fax: +82 2-745-8483; Tel: +82 2-740-8770

${ }^{b}$ Department of Agricultural Biotechnology \& Research Institute for Agriculture and Life Sciences, Seoul National University, Seoul, 151-921, Republic of Korea. E-mail: chocs@snu.ac.kr; Fax: +82 2-875-2494; Tel: +82 2-880-4868

${ }^{c}$ Y. B. Chavan College of Pharmacy, Dr Rafiq Zakaria Campus, Rauza Baugh, Aurangabad, 431001, India
} 